\title{
Study on the Personnel Training Mode of Application-oriented Undergraduates Majoring in Tourism Management Based on Occupation Groups
}

\author{
Sun Xuefei \\ Shanghai Business School \\ Shanghai, China \\ kf_rose@126.com
}

\author{
Shi Zhaoli \\ Henan University \\ Kaifeng, China \\ szl7031@163.com
}

\begin{abstract}
Through the analysis of the questionnaires and statistics of various occupation group managers, the paper finds out the common points and differences in the talent demand among different types of tourism enterprises, then makes exploration and innovation on the training mode of undergraduates whose major is Tourism Management Application.
\end{abstract}

Keywords-Occupation group; Tourism Management; Personnel training

\section{INTRODUCTION}

With the rapid development of China's economy and the increasing of people's income, tourism has become an increasingly important part of people's life, thus continuously upgrading the status of tourism industry. At the same time, with the development of leisure tourism, exhibition industry and theme park, there is a greater demand for tourism talents and higher requirements for the higher education of tourism in China.

The main purpose of China's higher tourism education is to cultivate high and middle level management personnels of tourism industry. Although there are large quantities of graduates from tourism colleges and universities every year, the phenomenon of "supply and demand dislocation" is quite serious. On the one hand, there is a short supply of management talents in tourism industry ; on the other hand, it is generally believed that the students have great ambition but little talents. In addition, tourism industry is a wide range subject, the concept of deep foundation and broad extension of professional knowledge has been recognized by the traditional undergraduate tourism education. But in recent years, along with the emergence and development of hotel management profession, exhibition management profession, the orientation and direction of undergraduate education of tourism management is setting us rethinking. Therefore, it has become an important issue of how to understand the differences of requirements of the tourism management undergraduates among different occupations and how to set up the cultivation mode of the tourism management talents that can meet the requirements of different occupation groups .

Based on the study of the training of tourism talents in recent years made by domestic and foreign experts and scholars, and according to the statistics and analysis of the questionnaire by travel agencies, hotels, exhibitions, scenic spots, entertainment and other occupation groups, this paper aims to find out the common points and differences in the talent demand among different types of tourism enterprises, then makes exploration and innovation on the training mode of undergraduates whose major is Tourism Management Application.

\section{SURVEY DATA}

Taking managers of Shanghai enterprises as the investigation objects, this study sent out a total of 200 questionnaires, took back 177 valid questionnaires, the effective recovery rate is $88.5 \%$.There are 38 people from the travel agency, 25 people from the hotel, 22 from the exhibition Festival , 41 from the scenic spots , 34from the leisure and entertainment and 17 from other occupation groups.

\section{THE COMMON REQUIREMENTS AND THE DIFFERENCES OF THE DIFFERENT ENTERPRISES FOR PERSONNELS OF TOURISM MANAGEMENT}

Through the analysis of the variance data, the statistical results show that the enterprise's demand for talents of tourism management is the combination of similarities and differences. The commonality refers to the conformity of the personnel's basic ability and quality required by the enterprises. The differences refer to the different types of talents needed by different types of enterprises from the aspects of different professional abilities, professional directions and professional qualities. From the perspective of the enterprise, the similarities and differences of the tourism management personnels fall mainly into the following three aspects: the individual's basic qualities, personal comprehensive ability and application ability.

\section{A. The basic qualities of an individual}

When asked "Do you think the following basic qualities of a person are important?", the $\mathrm{P}$ value of "hard-work", "service awareness", "appearance and grooming " is less than 0.1 , the result is not significant. The results show that there is a commonality and consistency for talents of the three basic quality requirements among the travel agencies, hotels, exhibition festivals, scenic spots, entertainment and leisure enterprises. They generally require the talents of tourism management can agree to bear hardships, have service consciousness and pay attention to their appearance.

Detailed in Table I . 
TABLE I. PREFERENCE OF BASIC QUALITIES OF A PERSON FROM DIFFERENT TYPES OF ENTERPRISES

\begin{tabular}{|c|c|c|c|c|c|c|}
\hline $\begin{array}{c}\text { Basic } \\
\text { Individual } \\
\text { Qualities }\end{array}$ & & SS & $\mathrm{DF}$ & MS & $\mathbf{F}$ & sig. \\
\hline \multirow[t]{2}{*}{ integrity } & $\begin{array}{l}\text { Among } \\
\text { Groups }\end{array}$ & 11.071 & 4 & 2.768 & 2.590 & $0.039(* *)$ \\
\hline & In Groups & 165.623 & 155 & 1.069 & & \\
\hline \multirow[t]{2}{*}{ hard-work } & $\begin{array}{l}\text { Among } \\
\text { Groups }\end{array}$ & 7.960 & 4 & 1.990 & 1.960 & 0.103 \\
\hline & In Groups & 157.384 & 155 & 1.015 & & \\
\hline \multirow{2}{*}{$\begin{array}{l}\text { service } \\
\text { awareness }\end{array}$} & $\begin{array}{l}\text { Among } \\
\text { Groups }\end{array}$ & 3.136 & 4 & 0.784 & 0.765 & 0.550 \\
\hline & In Groups & 158.839 & 155 & 1.025 & & \\
\hline \multirow[t]{2}{*}{ teamwork } & $\begin{array}{l}\text { Among } \\
\text { Groups }\end{array}$ & 9.117 & 4 & 2.279 & 2.059 & $0.089(*)$ \\
\hline & In Groups & 171.577 & 155 & 1.107 & & \\
\hline \multirow[t]{2}{*}{ literacy } & $\begin{array}{l}\text { Among } \\
\text { Groups }\end{array}$ & 9.406 & 4 & 2.351 & 1.979 & $0.100(*)$ \\
\hline & In Groups & 184.188 & 155 & 1.188 & & \\
\hline \multirow[t]{2}{*}{ grooming } & $\begin{array}{l}\text { Among } \\
\text { Groups }\end{array}$ & 1.827 & 4 & 0.457 & 0.437 & 0.782 \\
\hline & In Groups & 162.173 & 155 & 1.046 & & \\
\hline
\end{tabular}

** The mean difference is significant at the 0.05 level (2-tailed).

* The mean difference is significant at the 0.1 level (2-tailed)

While different enterprises have different demands on "integrity", "teamwork" and "literacy". In details, the scenic spots have higher requirements on the undergraduates' integrity and teamwork, while the travel agencies have a higher demanding of the personnels on their educational qualities and teamwork. In contrast, hotels and leisure entertainment enterprises have lower requirements for talents on their literacy qualities. Detailed in Figure 1,2,3.

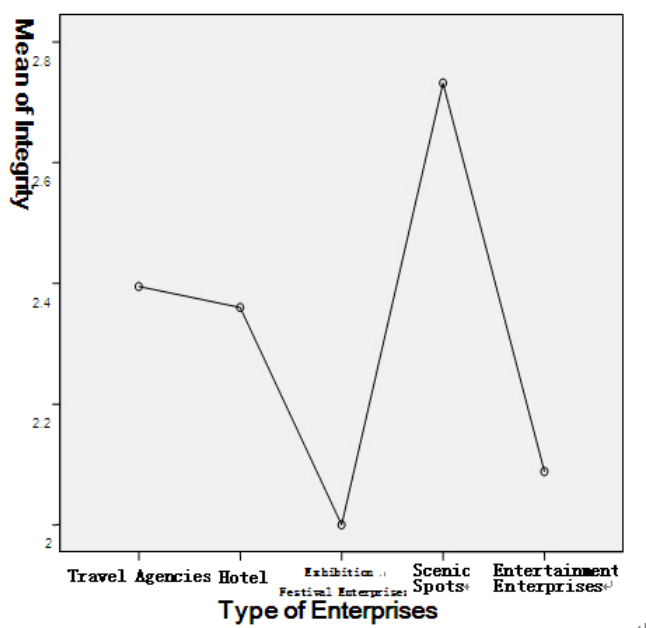

Figure 1. Preference of different types of enterprises of "integrity" quality

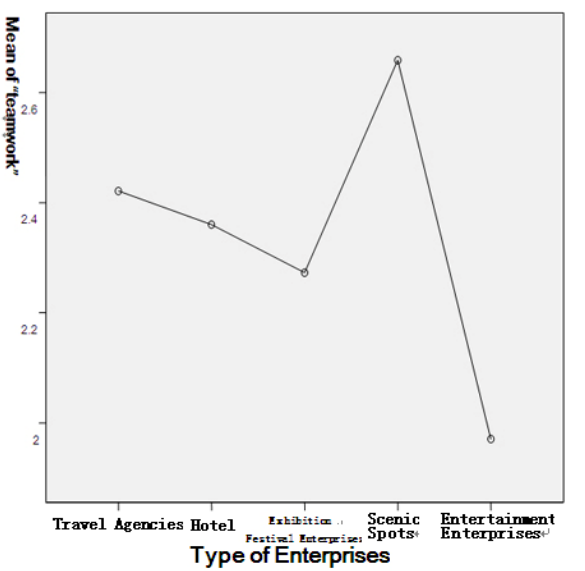

Figure 2. Preference of different types of enterprises of "teamwork" quality

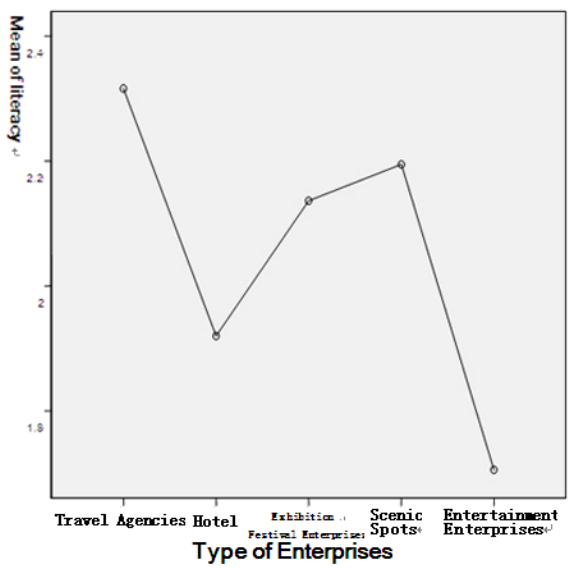

Figure 3. Preference of different types of enterprises of "literacy" quality 


\section{B. Personal comprehensive ability}

The difference of different types of enterprises' demand of the comprehensive ability of a talent is quite obvious, especially in the requirements of the individual's "marketing planning ability", "creative writing ability", "computer application ability", "innovative learning ability". Exhibition festival enterprises value a person's marketing planning ability and writing ability highly, while the travel agencies pay more attention on individuals' computer application ability, scenic spots speak highly of a person's innovative learning ability. Communication skills, management ability and financial management ability are the common requirements of each type of enterprises. Detailed in Table II.

\section{Professional application ability}

The requirements of each enterprise on the talent's professional application ability are generally higher. From the analysis of variance table, we can see that the common request is obvious, the $P$ value is greater than 0.1 and there is no significant difference. Detailed in Table III.

TABLE II. PREFERENCE OF DIFFERENT TYPES OF ENTERPRISES OF THE COMPREHENSIVE ABILITY OF A TALENT

\begin{tabular}{|c|c|c|c|c|c|c|}
\hline $\begin{array}{c}\text { Personal } \\
\text { Comprehensive } \\
\text { Ability }\end{array}$ & & SS & Df & MS & $\mathbf{F}$ & sig. \\
\hline \multirow{2}{*}{$\begin{array}{l}\text { Communication } \\
\text { skills }\end{array}$} & $\begin{array}{l}\text { Among } \\
\text { Groups }\end{array}$ & 7.408 & 4 & 1.852 & 1.627 & 0.170 \\
\hline & In Groups & 170.746 & 155 & 1.138 & & \\
\hline \multirow{2}{*}{$\begin{array}{l}\text { marketing planning } \\
\text { ability }\end{array}$} & $\begin{array}{l}\text { Among } \\
\text { Groups }\end{array}$ & 9.511 & 4 & 2.378 & 1.996 & $0.098(*)$ \\
\hline & In Groups & 178.657 & 155 & 1.191 & & \\
\hline \multirow[t]{2}{*}{ management ability } & $\begin{array}{l}\text { Among } \\
\text { Groups }\end{array}$ & 9.286 & 4 & 2.322 & 1.713 & 0.150 \\
\hline & In Groups & 203.269 & 155 & 1.355 & & \\
\hline \multirow{2}{*}{$\begin{array}{l}\text { creative } \\
\text { ability }\end{array}$} & $\begin{array}{l}\text { Among } \\
\text { Groups }\end{array}$ & 26.181 & 4 & 6.545 & 4.671 & $0.001(* *)$ \\
\hline & In Groups & 210.168 & 155 & 1.401 & & \\
\hline \multirow{2}{*}{$\begin{array}{l}\text { financial } \\
\text { management ability }\end{array}$} & $\begin{array}{l}\text { Among } \\
\text { Groups }\end{array}$ & 11.634 & 4 & 2.908 & 1.955 & 0.104 \\
\hline & In Groups & 223.166 & 155 & 1.488 & & \\
\hline \multirow{2}{*}{$\begin{array}{l}\text { computer application } \\
\text { ability }\end{array}$} & $\begin{array}{l}\text { Among } \\
\text { Groups }\end{array}$ & 16.699 & 4 & 4.175 & 3.458 & $0.010(* *)$ \\
\hline & In Groups & 181.069 & 155 & 1.207 & & \\
\hline \multirow{2}{*}{$\begin{array}{l}\text { innovative learning } \\
\text { ability }\end{array}$} & $\begin{array}{l}\text { Among } \\
\text { Groups }\end{array}$ & 24.316 & 4 & 6.079 & 4.574 & $0.002(* *)$ \\
\hline & In Groups & 199.361 & 155 & 1.329 & & \\
\hline
\end{tabular}

TABLE III. PREFERENCE OF DIFFERENT TYPES OF ENTERPRISES OF PROFESSIONAL APPLICATION ABILITY

\begin{tabular}{|l|l|l|l|l|l|l|}
\hline \multicolumn{1}{|c|}{$\begin{array}{c}\text { Professional } \\
\text { application ability }\end{array}$} & \multicolumn{1}{|c|}{ SS } & \multicolumn{1}{|c|}{ Df } & \multicolumn{2}{|c|}{ MS } & sig. \\
\hline $\begin{array}{l}\text { basic professional } \\
\text { knowledge }\end{array}$ & $\begin{array}{l}\text { Among } \\
\text { Groups }\end{array}$ & 5.159 & 4 & 1.290 & .964 & 0.429 \\
\cline { 2 - 7 } & In Groups & 200.751 & 155 & 1.338 & & 0.200 \\
\hline practice ability & $\begin{array}{l}\text { Among } \\
\text { Groups }\end{array}$ & 7.511 & 4 & 1.878 & 1.517 & 0.114 \\
\cline { 2 - 8 } & In Groups & 185.625 & 155 & 1.237 & & 1.896 \\
\hline practice experience & $\begin{array}{l}\text { Among } \\
\text { Groups }\end{array}$ & 9.927 & 4 & 2.482 & & \\
\cline { 2 - 7 } & In Groups & 196.292 & 155 & 1.309 & & \\
\hline
\end{tabular}

TABLE IV. GENERAL REQUIREMENTS FOR TOURISM MANAGEMENT PROFESSIONALS OF DIFFERENT TYPES OF ENTERPRISES

\begin{tabular}{|l|l|l|}
\hline \multicolumn{1}{|c|}{$\mathbf{1}$ Basic Individual Qualities } & 2 Individual comprehensive ability & 3Professional application ability \\
\hline hard-work & Communication skills & professional Basic knowledge \\
\hline service awareness & management ability & practice ability \\
\hline grooming & Financial management ability & practice experience \\
\hline teamwork & creative writing ability & \\
\hline integrity & marketing planning ability & \\
\hline literacy & computer application ability & \\
\hline & innovative learning ability & \\
\hline
\end{tabular}




\section{TRAINING STRATEGIES OF APPLICATION-ORIENTED UNDERGRADUATES WHOSE MAJOR IS TOURISM \\ MANAGEMENT ACCORDING TO DIFFERENT OCCUPATION GROUPS}

\section{A. Make strict practice evaluation system, improve the basic quality of a person}

Through the questionnaire we can see that each occupation group values the personal qualities such as hardworking, service awareness and grooming, which is precisely the characteristics of the tourism industry. Most students are growing up under the favourable environment resulting in the scarce of hard-working, teamwork and service consciousness among them. While in the current curriculum system, only teaching practice is to train and to evaluate students' basic individual qualities, which is often not strict enough. So the students are prone to cope with the teaching practice, having little effect on the training of students' basic individual qualities. So effective mechanism of training should be established. Through the method of giving lectures, setting examples, we can guide students' concepts, strengthen the training by adding the team development courses, make strict evaluation on the students' basic qualities in the teaching system.

\section{B. Add more courses in curriculum and establish the comprehensive capacity evaluation system}

Through the questionnaire we found that tourism enterprises pay more attention to the individual's qualities of language communication, management decision, financial management, writing, computer application, marketing planning, creative and personal comprehensive abilities. Different types of enterprises have focused on different comprehensive abilities. The cultivation of comprehensive abilities should run through the whole teaching scheme. Thus not only more courses should be added to the curriculum, but also the evaluation should be more specific and be combined with practice. Comprehensive capacity evaluation system should be established. For example, the evaluation of language communication ability is reflected in the fluency of English conversation, excellent speech ability, outstanding telesales skills etc.. In practice, the evaluation system can be strengthened by taking part in the speech contests, simulating product sales, having English tour guide qualification certificate and so on.

\section{Set up accurate elective courses and refine the core foundation of tourism industry}

Through the questionnaire, it is revealed that all tourism enterprises attach great importance to the application ability. But different occupation groups are completely different at the course's representation of the application ability, with a strong tendency of occupation. At present, tourism management in the 2012 "Undergraduate professional directory of ordinary higher college" includes three secondlevel disciplines: tourism management, hotel management, exhibition economy and management. The two majors -hotel and exhibition, have clear professional tendency in the tourism industry. Tourism management is the subject applied for the whole tourism industry. So, it should be included in the curriculum and should be included in the optional course by refining 3-5 core courses to meet the students' need of finding a job. At the same time differences of different occupation groups' demand on comprehensive ability should also be taken into account. Emphasis should be given on refining professional core courses. For instance, the travel agency emphasizes on the computer application ability, application courses like the travel agency management application system can be added to the curriculum; the exhibition enterprise emphasizes on the marketing planning ability and writing ability, courses like the exhibition planning and Exhibition copy can be added to the curriculum.

In short, the undergraduates of tourism management should have deep foundation and broad extension of professional knowledge and have strong practical ability. Under the new situation, graduates of college should not only have excellent entry skills, but also have a comprehensive ability. In the construction of the training mode of application-oriented Tourism Management undergraduates, we should cultivate students' vocational skills through refining professional core courses and practical teaching. We should cultivate students' comprehensive ability through the comprehensive evaluation system to embody the occupational growth of the undergraduate students.

\section{REFERENCES}

[1] Ling Qian.Strategies of Cultivating Employment-oriented Talents of Tourism Management in University [J].Science Educ,2011,( 2): 3536

[2] $\mathrm{Xu}$ Jinsong.The Training of Applied Innovative Talents - - Concept - Principle - Mechanism[J]. Theory and Practice of Education,2011,(6):3-5

[3] Hong Meixiang etc.Building the Quality Evaluation System of Training Talents of Tourism Based on AHP[J]. Economic Research Guide,2011,(3):173-174

[4] Chen Ping. A Study of Teachers Resistance of the Reform of Applied Undergraduate Personnel Training [J]. Theory and Practice of Education,2011,(6):41-43

[5] Su Zhiping. A Probe into Training Mode of Applied Professionals for Tourism in Independent Colleges [J] .Theory and Practice of Education, 2010,( 18):12-13

[6] Chen Chengguo.Investigation and Consideration of the Employment Situation of the Tourism Management Graduates in University [J].Journal of Chongqing University of Science and Technology(Social Sciences Edition),2010,(9):193-194 